\title{
Response of Caenorhabditis elegans during subsequent infections with Gram positive and Gram negative bacteria
}

\author{
Gnanasekaran Jeba Mercy ${ }^{*}$ Krishnaswamy Balamurugan \\ From First International Science Symposium on HIV and Infectious Diseases (HIV SCIENCE 2012) \\ Chennai, India. 20-22 January 2012
}

\section{Background}

The nematode Caenorhabditis elegans is one of the popular model hosts for the study of the evolutionarily conserved mechanism of microbial pathogenesis and innate immunity. C. elegans can be effectively used to study the dynamics of polymicrobial infections. Proteus mirabilis, an opportunistic pathogen, does not cause death in $C$. elegans. In this study the C. elegans was pre-infected with Staphylococcus aureus to make the C. elegans immunocompromised to study the effect of $P$. mirabilis in the host.

\section{Methods}

This study involved in investigation of impact of subsequent infections at both physiological and molecular levels using $C$. elegans by killing assays and real time PCR analysis.

\section{Results}

The study revealed that $12 \mathrm{~h}$ of $S$. aureus and $80 \mathrm{~h}$ of $P$. mirabilis subsequent infections reduced the life-span of $80 \%$ of the infected nematodes. Real time PCR analyses indicated the regulation of innate immune regulatory genes, lysozyme, CUB-like proteins, neuropeptide-like factors, transcription factors of MAP kinase and daf-2daf-16, insulin-like signaling pathways and C-type lectin family members during polymicrobial infections, indicating possible role and contribution of the above players during host immune response against subsequent infections.

* Correspondence: bsuryar@yahoo.com

Department of Biotechnology, Alagappa University, Karaikudi-630 003, Tamil Nadu, India

\section{Conclusions}

Our findings demonstrate that the vulnerability of a host is an integral part of the $S$. aureus infection that enables the bacteria to subvert the host immune system, which can lead to the $P$. mirabilis to exert its pathogenicity in the host C. elegans.

Published: 4 May 2012

doi:10.1186/1471-2334-12-S1-P44

Cite this article as: Mercy and Balamurugan: Response of Caenorhabditis elegans during subsequent infections with Gram positive and Gram negative bacteria. BMC Infectious Diseases 2012 12(Suppl 1):P44.
Submit your next manuscript to BioMed Central and take full advantage of:

- Convenient online submission

- Thorough peer review

- No space constraints or color figure charges

- Immediate publication on acceptance

- Inclusion in PubMed, CAS, Scopus and Google Scholar

- Research which is freely available for redistribution

\section{( Biomed Central}

